\title{
Trend Analysis of Total Affected Water and Total Discharged Wastewater of Nišava District (Serbia)
}

\author{
Nina Pavićević* \\ Megatrend University of Belgrade, Faculty of Management Zaječar, 19000 Zaječar, Serbia
}

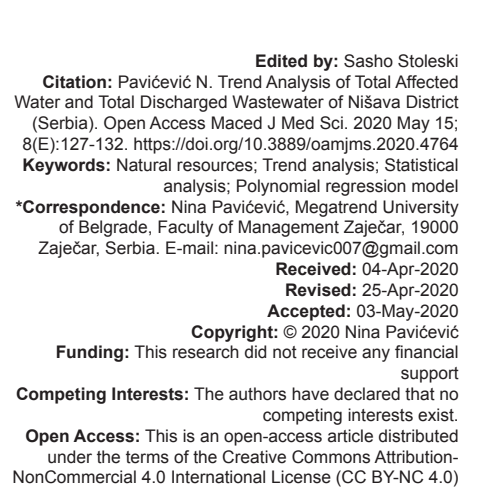

Introduction

Natural resources (NR) are raw organic materials or substances, which are found in nature, and represent the general natural wealth which has usable value and can be used for industrial production and/or consumption [1], [2], [3], [4].

NR represents the natural wealth of a country or region include of minerals, petroleum, natural gas, coal, metals, stone, sand, air, sunlight, forests, land, and water. In papers George and Schillebeeckx [5] and George et al. [6] are given of the management of NR and in papers Nelson et al. [7], Smith [8], Tarasyev et al. [9], and Tarasyev et al. [10] are given of statistical analysis of different NR.

There are NRs that are subject to depletion by human use and that can be processed through various production processes into a product, and thus have a usable and economic value. Such NRs (PR) can be subdivided into four categories: Mineral and energy resources, soil and land resources, water resources, and biological resources.

Based on the type of reproducibility, many NRs are usually divided into two types [1] (Figure 1):

Renewable resources are resources that can naturally replenish (sunlight, air, forests, wind,

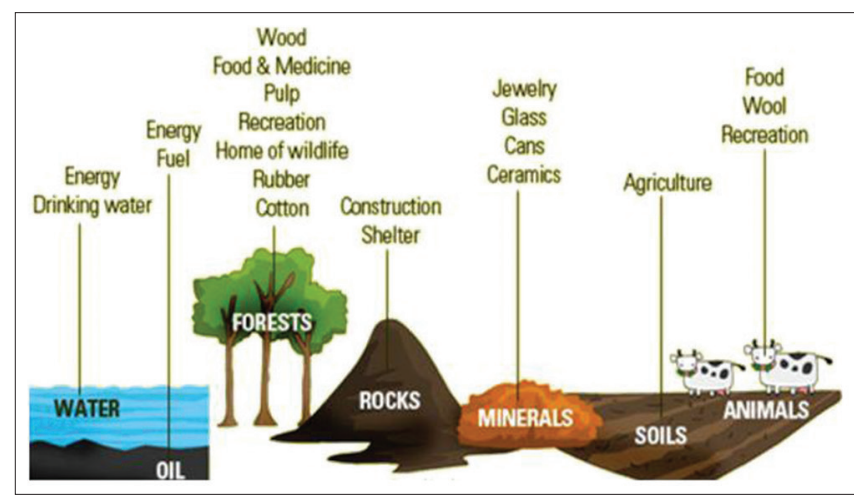

Figure 1: Different types of natural resources: Renewable and nonrenewable resources

water, etc.) and their consumption is slightly affected by human consumption and

Non-renewable resources are resources that do not naturally form in the environment or are slowly being formed and/or renewed (land, fossil fuels, crude oil, natural gas, coal, various types of stone, metals, uranium, and other materials and minerals, etc.).

On the basis of origin, NRs are divided into two types [1]:

Biotic resources are resources obtained from the biosphere (living and organic material such as forests, animals, and plants), fossil fuels such as coal 
and petroleum because they are formed from decayed organic matter, etc., and

Abiotic resources are resources that come from non-living (inanimate), non-organic material (land, water, air, minerals, rare earth metals, and heavy metals, including ores, such as gold, iron, copper, and silver).

Water, as an NR, is the most basic material of life that has immeasurable significance for the living world, ecosystems, and planet Earth. Water is constantly circulating in nature between the Earth and the atmosphere, and at the same time, enables life to be maintained. Water moves, changing its appearance, but it never really disappears. The water that is consumed has been on Earth for hundreds of millions of years. It is consumed by plants, animals, and humans.

The most important characteristic of water is its quality, which is assessed by the so-called water quality index (WQI). Analysis of WQI index in different regional territories is presented in the following papers Aščić and Imamović [11], Bordalo et al. [12], Egborge and BenkaCoker [13], Elezović et al. [14], Selvam et al. [15], and Von der Ohe et al. [16], WQI index as management tool is given in paper Ferreira et al. [17], and as classification tool is given in papers Boyacioglu [18] and Kannel et al. [19], for water quality is given in papers Gupta et al. [20] and Kaurish and Younos [21], for prediction of WQI index is given in paper Rene and Saidutta [22], etc.

In paper is given a trend analysis of total affected quantities of water and total discharged wastewater (TDWW) of Nišava district (Serbia).

\section{Data and Methods}

Data on values of total affected quantities of water, TDWW, etc., of Nišava district (Serbia), are taken from "Municipalities and Regions in the Republic of Serbia" of the Statistical Office of the Republic of Serbia for the period 2006-2018 [23], [24], [25], [26], [27], with significant calculations by the authors.

In the Nišava district, the following municipalities are (Figure 2): Niš, Aleksinac, Gadžin Han, Doljevac, Merošina, Ražanj, and Svrljig.

The total area for Nišava district in 2018 is $2728 \mathrm{~km}^{2}$. Population in Nišava district in 2002 is 381757 (of these men are: 187780 and the woman is: 193977) and in 2018 is 362331 [27], which is less for 19426 or compound annual growth rate $(\mathrm{CAGR})=-0.33 \%$ and cumulative growth index $(\mathrm{CGI})=94.91 \%$.

In 2018, the total number of employees registered was 106931 (of these men: 55063 and the women: 51868), while the number of employees per 1000 population was 295 .

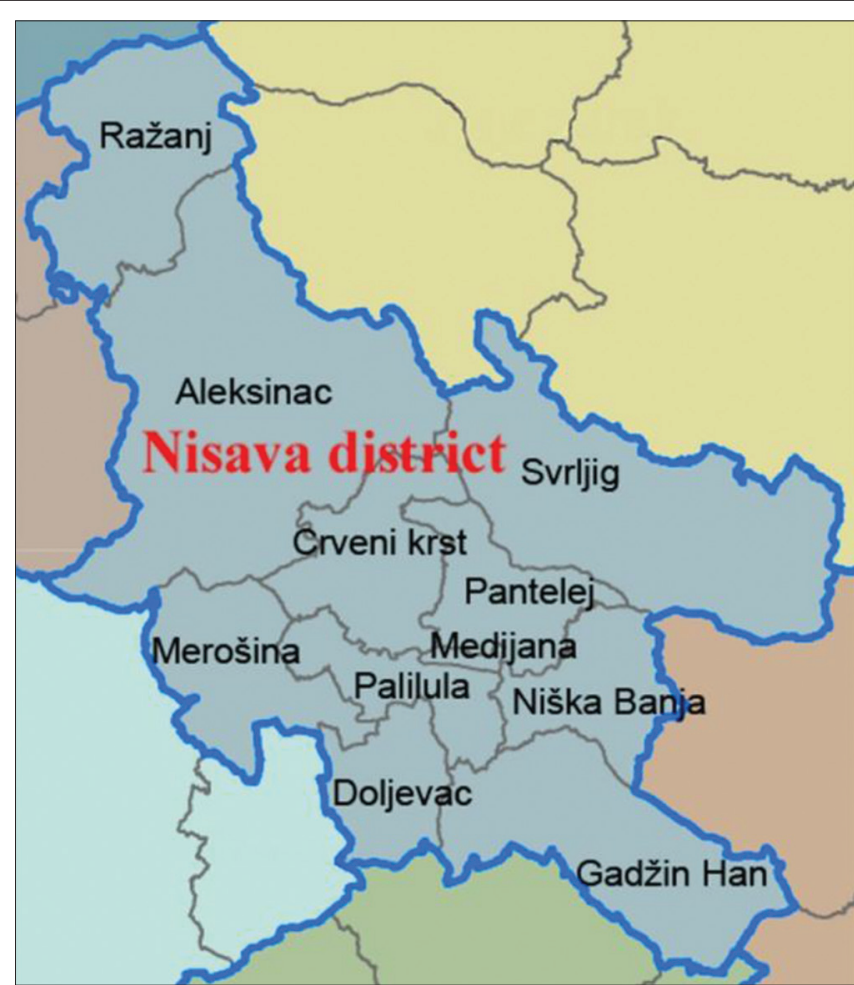

Figure 2: Map of Nišava district

For the trend analysis, we used the following parameters: AGR, CAGR, and CGI described in the papers Dašić [28], Dašić et al., [29], Tošović et al., [30], Turmanidze et al., [31], etc.

Standard statistical analysis methods and MS-Excel software system were used to calculate the statistical descriptions parameter, graphical representation of data, and approximation of the total affected quantities of water and TDWW for Nišava district (Serbia) [32], [33], [34].

\section{Results and Discussion}

In Table 1, data are given about total affected quantities of water, delivered quantities of drinking water (DQDW), TDWW, wastewater discharges to wastewater systems, and number of households connected to the water supply network for Nišava district (Serbia) for the period 20062018 [23], [24], [25], [26], [27].

Trend analysis for total affected quantities of water $\left(\times 10^{3} \mathrm{~m}^{3}\right)$ for Nišava district (Serbia) for the period 2006-2018 is shown in Figure 3.

The data about total affected quantities of water $\left(\times 10^{3} \mathrm{~m}^{3}\right)$ for Nišava district (Serbia) for the period 2006-2018 changed in intervals from 5783 to 41740, with arithmetic mean $A M=25771.85$ and median is $\mathrm{Med}=37782$. Standard deviation is $S D=15831.5$ and coefficient of variation is $\mathrm{CoV}=61.43$. 
Table 1: Data on water supply and wastewater for Nišava district for the period 2006-2018

\begin{tabular}{lllll}
\hline Year & $\begin{array}{l}\text { Total affected quantities of water } \\
\left(\times 103 \mathrm{~m}^{3}\right)\end{array}$ & $\begin{array}{l}\text { Delivered quantities of drinking water } \\
\left(\times 103 \mathrm{~m}^{3}\right)\end{array}$ & $\begin{array}{l}\text { Total discharged waste water } \\
\left(\times 103 \mathrm{~m}^{3}\right)\end{array}$ & $\begin{array}{l}\text { Wastewater discharges to wastewater } \begin{array}{l}\text { Number of households connected } \\
\text { systems }\left(\times 103 \mathrm{~m}^{3}\right)\end{array} \\
\text { to the water supply network }\end{array}$ \\
\hline 2006 & 41740 & 23777 & 19097 & - \\
2007 & 40536 & 25418 & 18940 & - \\
2008 & 38965 & 24214 & 17967 & - \\
2009 & 37782 & 22982 & 15964 & 15964 \\
2010 & 38045 & 23099 & 16820 & 16820 \\
2011 & 40051 & 22918 & 16287 & 16287 \\
2012 & 41314 & 23030 & 22393 & 16661 \\
2013 & 8871 & 23018 & 22374 & 16576 \\
2014 & 5783 & 19805 & 19411 & 16046 \\
2015 & 10378 & 23306 & 22669 & 17181 \\
2016 & 10726 & 21775 & 21247 & 16765 \\
2017 & 10912 & 21180 & 20651 & 15887 \\
2018 & 9931 & 20402 & 19897 & 15357 \\
\hline
\end{tabular}

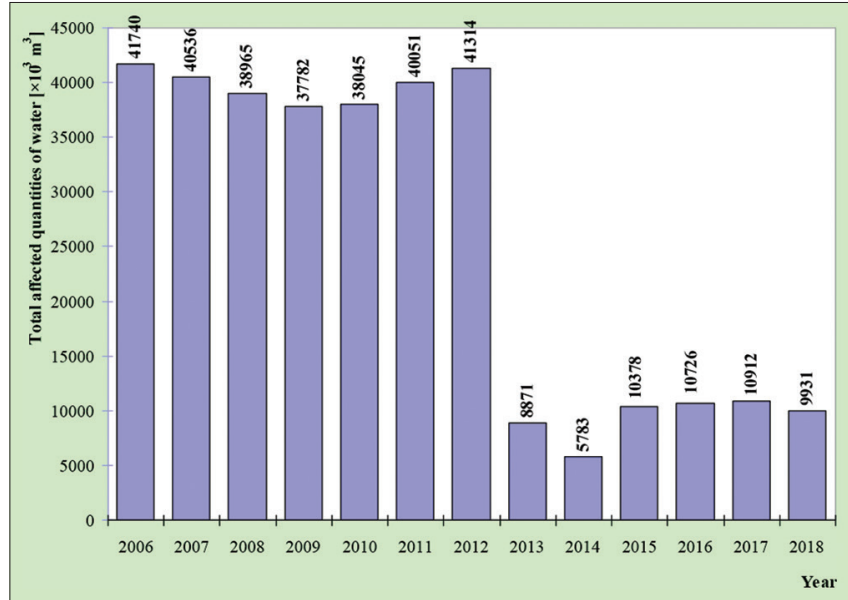

Figure 3: Trend analysis for total affected quantities of water $\left(\times 10^{3} \mathrm{~m}^{3}\right)$ for Nišava district (Serbia) for the period 2006-2018

Values of trend analysis are $\mathrm{CGI}=23.79 \%$ in 2018 compared to 2006 and $\mathrm{CAGR}=-8.58 \%$ per year for the period 2006-2018.

Trend analysis for DQDW $\left(\times 10^{3} \mathrm{~m}^{3}\right)$ for Nišava district (Serbia) for the period 2006-2018 is shown in Figure 4.

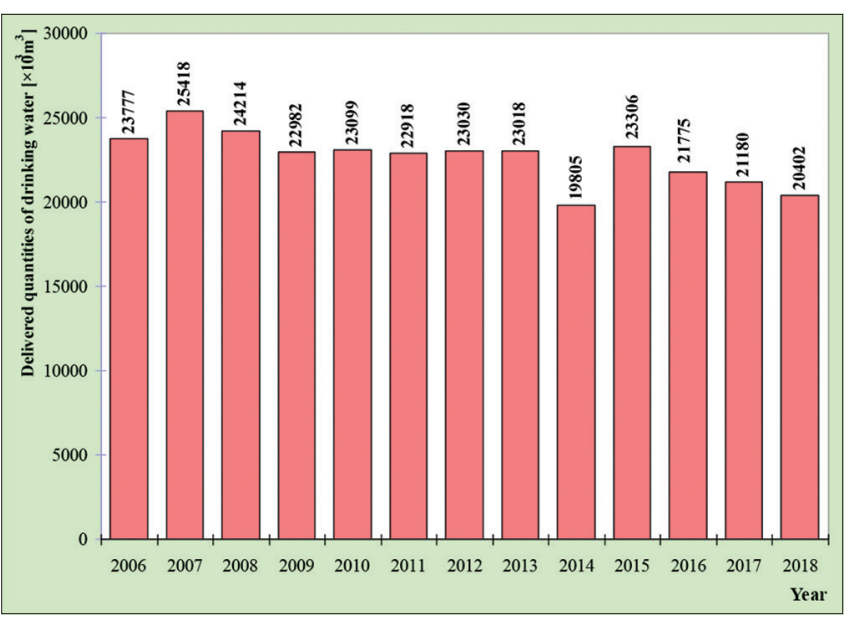

Figure 4: Trend analysis for delivered quantities of drinking water $\left(\times 10^{3} \mathrm{~m}^{3}\right)$ for Nišava district (Serbia) for the period 2006-2018

The data about DQDW $\left(\times 10^{3} \mathrm{~m}^{3}\right)$ for Nišava district (Serbia) for the period 2006-2018 changed in intervals from 19805 to 25418 , with $\mathrm{AM}=22686.46$ and Med $=23018$. Standard deviation is $S D=1541.88$ and $\mathrm{CoV}=6.80$.
Values of trend analysis are $\mathrm{CGI}=85.81 \%$ in 2018 compared to 2006 and CAGR $=-0.95 \%$ per year for the period 2006-2018.

The data about DQDW $\left(\times 10^{3} \mathrm{~m}^{3}\right)$ for Nišava district (Serbia) for the period 2006-2018 can be approximated using a linear regression model (LRM) which has the form (Figure 5):

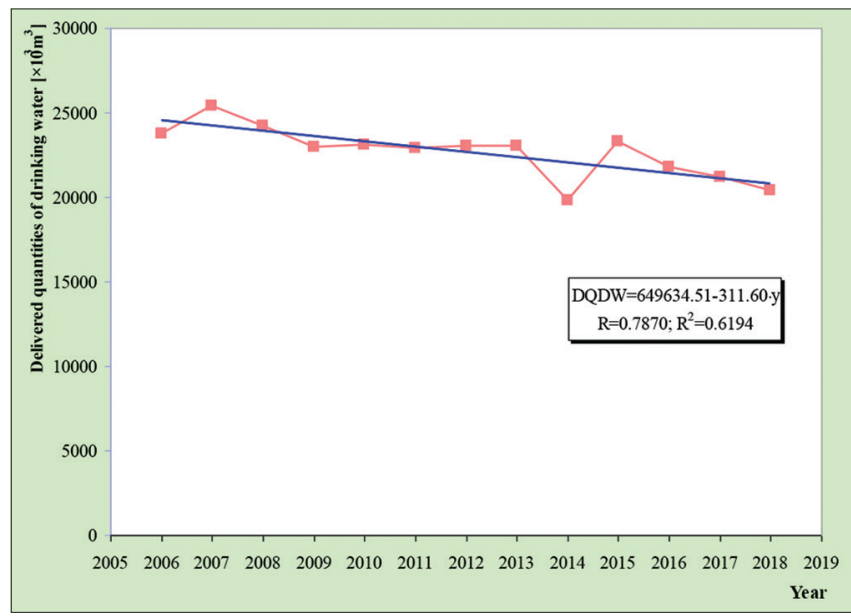

Figure 5: Approximated delivered quantities of drinking water $\left(\times 10^{3} \mathrm{~m}^{3}\right)$ for Nišava district (Serbia) for the period 2006-2018 using linear regression

$$
\mathrm{DQDW}=649634.51-311.60 \times \mathrm{y}
$$

With coefficient of correlation is $R=0.7870$, coefficient of determination is $\mathrm{R}^{2}=0.6194$.

Where: $y$-year and DQDW-DQDW $\left(\times 10^{3} \mathrm{~m}^{3}\right)$.

Trend analysis for TDWW $\left(\times 10^{3} \mathrm{~m}^{3}\right)$ for Nišava district (Serbia) for the period 2006-2018 is shown in Figure 6.

The data about TDWW $\left(\times 10^{3} \mathrm{~m}^{3}\right)$ for Nišava district (Serbia) for the period 2006-2018 changed in intervals from 15964 to 22669 , with $\mathrm{AM}=19516.69$ and Med $=19411$. Standard deviation is $S D=2310.23$ and CoV=11.84

Values of trend analysis are CGI $104.19 \%$ in 2018 compared to 2006 , and CAGR $=0.26 \%$ per year for the period 2006-2018.

The data about TDWW $\left(\times 10^{3} \mathrm{~m}^{3}\right)$ for Nišava district (Serbia) for the period 2006-2018 can be approximated using $6^{\text {th }}$-degree polynomial regression model (PRM6) which has the form (Figure 7): 


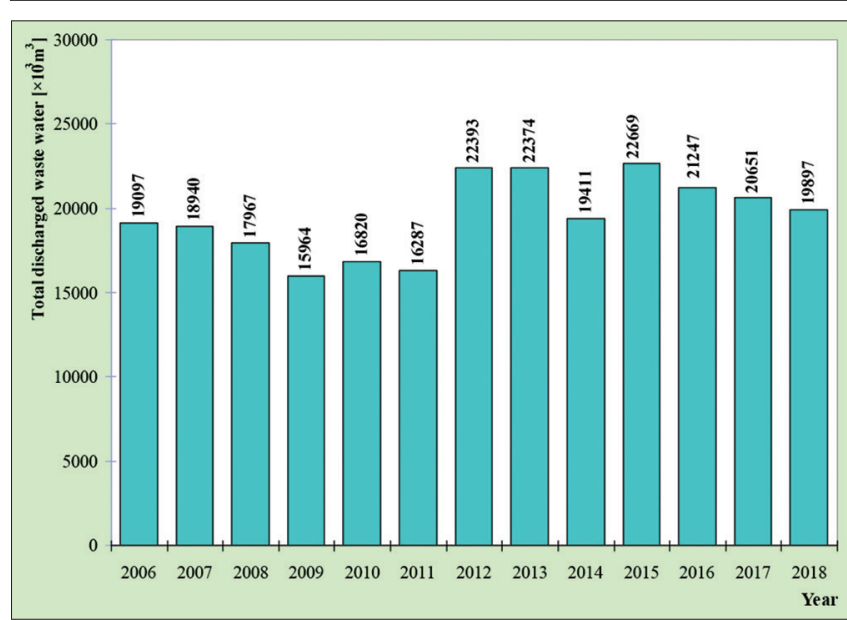

Figure 6: Trend analysis for total discharged wastewater $\left(\times 10^{3} \mathrm{~m}^{3}\right)$ for Nišava district (Serbia) for the period 2006-2018

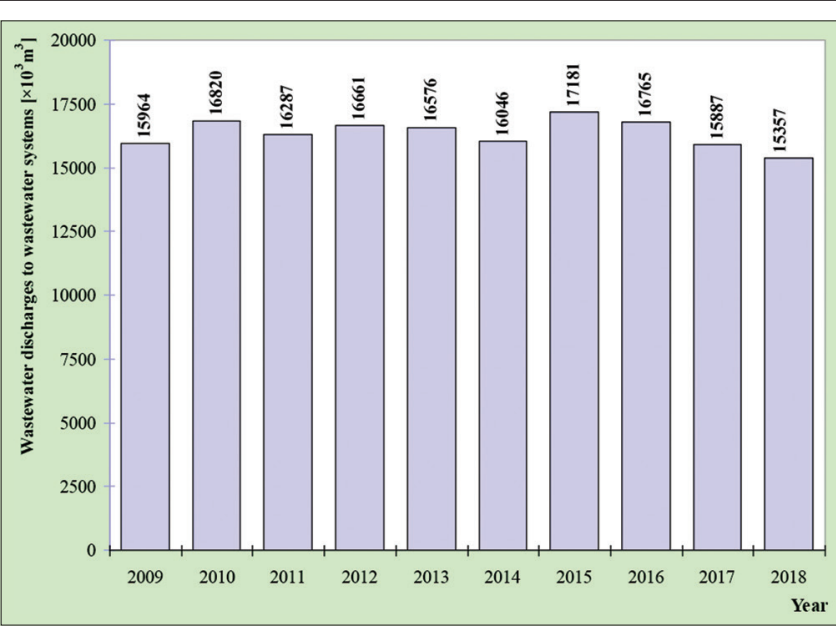

Figure 8: Trend analysis for wastewater discharges to wastewater systems $\left(\times 10^{3} \mathrm{~m}^{3}\right)$ for Nišava district (Serbia) for the period 2009-2018

Trend analysis for number of households connected to the sewer network for Nišava district (Serbia) for the period 2007-2018 is shown in Figure 9.

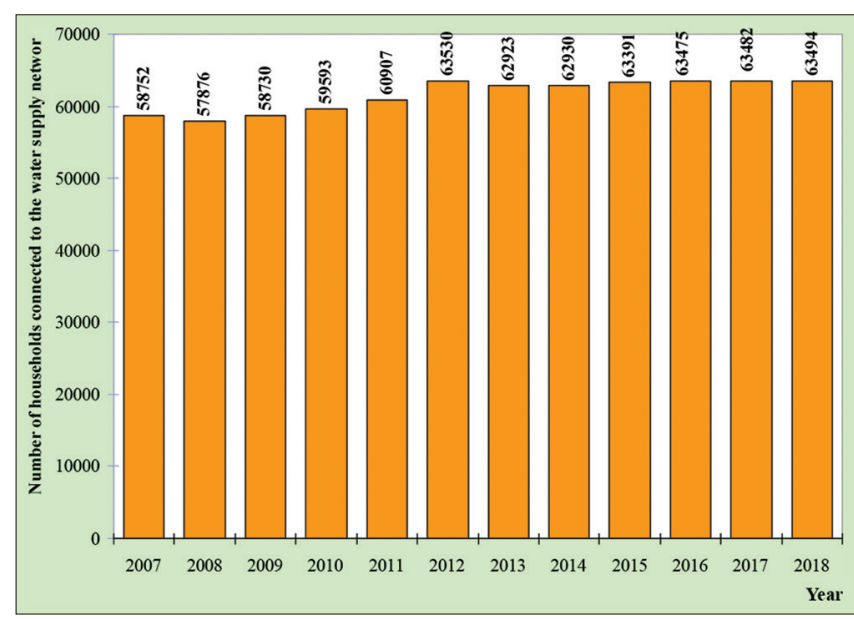

Figure 9: Trend analysis for number of households connected to the sewer network for Nišava district (Serbia) for the period 2007-2018

The data about number of households connected to the sewer network for Nišava district (Serbia) for the period 2007-2018 changed in intervals from 57876 to 63530 , with $A M=61590.25$ and Med $=62926.5$. Standard deviation is $S D=2252.67$ and $\mathrm{CoV}=3.66$.

Values of trend analysis are $\mathrm{CGI}=108.07 \%$ in 2018 compared to 2007 and CAGR $=0.49 \%$ per year for the period 2007-2018.

\section{Conclusion}

Values for total affected quantities of water $\left(\times 10^{3} \mathrm{~m}^{3}\right)$ for Nišava district (Serbia) for the period 2006-2018, they decreased from 41740 in 2006 to 9931 in 2018 (CGI=23.79\% in 2018 compared to 2006 and $C A G R=-8.58 \%$ per year). 
Values for DQDW $\left(\times 10^{3} \mathrm{~m}^{3}\right)$ for Nišava district (Serbia) for the period 2006-2018, they decreased from 23777 in 2006 to 20402 in 2018 (CGI=85.81\% in 2018 compared to 2006 and CAGR $=-0.95 \%$ per year).

Values for TDWW $\left(\times 10^{3} \mathrm{~m}^{3}\right)$ for Nišava district (Serbia) for the period 2006-2018, they increased from 19097 in 2006 to 19897 in 2018 (CGI=104.19\% in 2018 compared to 2006 and CAGR $=0.26 \%$ per year).

Values for wastewater discharges to wastewater systems $\left(\times 10^{3} \mathrm{~m}^{3}\right)$ for Nišava district (Serbia) for the period 2009-2018, they decreased from 15964 in 2009 to 15357 in 2018 (CGI=96.20\% in 2018 compared to 2006 and $C A G R=-0.24 \%$ per year).

Values for number of households connected to the sewer network for Nišava district (Serbia) for the period 2007-2018, they increased from 58752 in 2007 to 63494 in 2018 (CGI=108.07\% in 2018 compared to 2006 and $C A G R=0.49 \%$ per year).

Values for DQDW $\left(\times 10^{3} \mathrm{~m}^{3}\right)$ for Nišava district (Serbia) for the period 2006-2018 is approximated by LRM (eq. 1), with $R=0.7870$ and $R^{2}=0.6194$.

Values for TDWW $\left(\times 10^{3} \mathrm{~m}^{3}\right)$ for Nišava district (Serbia) for the period 2006-2018 is approximated by 6PRM6 (eq. 2), with $R=0.8515$ and $R^{2}=0.7251$.

\section{References}

1. Barbier EB. Natural Resources and Economic Development. $2^{\text {nd }}$ ed. Cambridge, UK: Cambridge University Press; 2019.

2. Andersen AD. Towards a new approach to natural resources and development: The role of learning, innovation and linkage dynamics. Int J Technol Learn Innov Dev. 2012;5(3):291-324. https://doi.org/10.1504/ijtlid.2012.047681

3. Salvati L, Marco Z. Natural resource depletion and economic performance of local districts: Suggestions from a within-country analysis. J Sustain Dev World Ecol. 2008;15(6):518-23. https:// doi.org/10.1080/13504500809469847

4. Schilling $M$, Chiang $L$. The effect of natural resources on sustainable development policy: The approach of nonsustainable externalities. Energy Policy. 2011;39(2):990-8. https://doi.org/10.1016/j.enpol.2010.11.030

5. George G, Schillebeeckx SJ. Managing Natural Resources: Organizational Strategy, Behaviour and Dynamics. Cheltenham, UK: Edward Elgar Publishing Ltd.; 2018. https:// doi.org/10.4337/9781786435729

6. George G, Schillebeeckx SJ, Liak TL. The management of natural resources: An overview and research agenda. Acad Manage J. 2015;58(6):1595-613. https://doi.org/10.5465/ amj.2015.4006

7. Nelson SL, Hudson JW, Hooker A. The use of statistical analysis to optimize pioneer natural resources' vertical spraberry-trend portfolio. SPE Econ Manage. 2013;5(3):105-17. https://doi. org/10.2118/162927-pa.

8. Smith VK. Natural resource scarcity: A statistical analysis. Rev Econ Stat. 1979;61(3):423-7. https://doi. org/10.2307/1926071

9. Tarasyev AM, Vasilev J, Turygina VF. Statistical analysis and forecasting of extraction and use of natural resources. AIP Conf Proc. 2018;2040:050011. https://doi.org/10.1063/1.5079109.

10. Tarasyev AM, Vasilev JA, Turygina VF, Kravchuk SV, Strelchuk AE. Methods for predicting the production of natural resources AIP Conf Proc. 2019;2186:050010. https://doi. org/10.1063/1.5137943.

11. Aščić A, Imamović M. Statistical descriptions of delivered quantity of water by sources in the federation of Bosnia and Herzegovina. MATEC Web Conf 2017;126:04007. https://doi. org/10.1051/matecconf/201712604007.

12. Bordalo AA, Teixeira R, Wiebe WJ. A water quality index applied to an international shared river basin: The case of the Douro River. Environ Manage. 2006;38(6):910-20. https://doi. org/10.1007/s00267-004-0037-6 PMid:17039391

13. Egborge $A B$, Benka-Coker J. Water quality index: Application in the Warri River, Nigeria. Environ Pollut Ser B. 1986;12(1):27-40. https://doi.org/10.1016/0143-148x(86)90004-2.

14. Elezović N, llić-Komatina D, Dervišević I, Ketin $S$, Dašić $P$. Analysis of SWQI index of the river Ibar (Serbia). Fresenius Environ Bull. 2018;27(4):2505-9.

15. Selvam $S$, Manimaran $G$, Sivasubramanian $P$ Balasubramanian N, Seshunarayana T. GIS-based evaluation of water quality index of groundwater resources around Tuticorin coastal city, South India. Environ Earth Sci. 2014;71(6):284767. https://doi.org/10.1007/s12665-013-2662-y

16. Von der Ohe CP, Prüß A, Schäfer RB, Liess M, De Deckere E, Brack W. Water quality indices across Europe-a comparison of the good ecological status of five river basins. J Environ Monit. 2007;9(9):970-8. https://doi.org/10.1039/b704699p PMid: 17726558

17. Ferreira NC, Bonetti C, Seiffert WQ. Hydrological and water quality indices as management tools in marine shrimp culture. Aquaculture. 2011;318(3-4):425-33. https://doi.org/10.1016/j. aquaculture.2011.05.045

18. Boyacioglu $\mathrm{H}$. Utilization of the water quality index method as a classification tool. Environ Monit Assess. 2010;167(1-4):115-24. https://doi.org/10.1007/s10661-009-1035-1

PMid:19543993

19. Kannel PR, Lee S, Lee YS, Kanel SR, Khan SP. Application of water quality indices and dissolved oxygen as indicators for river water classification and urban impact assessment. Environ Monit Assess. 2007;132(1-3):93-110. https://doi.org/10.1007/ s10661-006-9505-1

PMid: 17279460

20. Gupta AK, Gupta SK, Patil RS. A comparison of water quality indices for coastal water. J Environ Sci Health Part A Toxic Hazard Subst Environ Eng. 2003;38(11):2711-25. https://doi. org/10.1081/ese-120024458

PMid:14533934

21. Kaurish FW, Younos T. Developing a standardized water quality index for evaluating surface water quality. J Am Water Resour Assoc. 2007;43(2):533-45. https://doi. org/10.1111/j.1752-1688.2007.00042.x

22. Rene ER, Saidutta MB. Prediction of water quality indices by regression analysis and artificial neural networks. Int $\mathrm{J}$ Environ Res. 2008;2(2):183-8.

23. Kovačević M. Municipalities in the Serbia, 2006. Belgrade, Serbia: Republican Bureau of Statistics of Serbia; 2007.

24. Milojić A. Municipalities in the Serbia, 2010. Belgrade, Serbia: Republican Bureau of Statistics of Serbia; 2010.

25. Milojić A. Municipalities and Regions in the Republic of Serbia, 2014. Belgrade, Serbia: Republican Bureau of Statistics of Serbia; 2014

26. Gavrilović D. Municipalities and Regions in the Republic of 
Serbia, 2016. Belgrade, Serbia: Republican Bureau of Statistics of Serbia; 2016.

27. Gavrilović D. Municipalities and Regions in the Republic of Serbia, 2019. Belgrade, Serbia: Republican Bureau of Statistics of Serbia; 2019.

28. Dašić P. Application of polynomial regression models for approximation of time series. J Econ Manage Based New Technol. 2012;1(2):81-160.

29. Dašić $P$, Dašić J, Antanasković $D$, Pavićević N. Statistical analysis and modeling of global innovation index (GII) of Serbia. In: Lecture Notes in Networks and Systems. Berlin, Germany: Springer; 2020;128:515-21. https://doi. org/10.1007/978-3-030-46817-0_59.

30. Tošović R, Dašić P, Ristović I. Sustainable use of metallic mineral resources of Serbia from an environmental perspective. Environ Eng Manage J. 2016;15(9):2075-84. https://doi.org/10.30638/ eemj.2016.224

31. Turmanidze $R$, Dašić $P$, Popxadze, G. Statistical analysis of e-government development index (EGDI) of Georgia. In: Lecture Notes in Networks and Systems. Berlin, Germany: Springer; 2020;128:930-8. https://doi. org/10.1007/978-3-030-46817-0_105.

32. Cowan G. Statistical Data Analysis. New York, USA: Oxford University Press; 1998.

33. Schmuller J. Statistical Analysis with Excel for Dummies. $4^{\text {th }}$ ed. Hoboken, New Jersey, USA: John Wiley \& Sons Inc.; 2016.

34. Winston W. Microsoft Excel Data Analysis and Business Modeling. $5^{\text {th }}$ ed. Redmond, Washington, USA: Microsoft Press; 2016. 